medRxiv preprint doi: https://doi.org/10.1101/2020.04.01.20049478; this version posted April 6, 2020. The copyright holder for this preprint (which was not certified by peer review) is the author/funder, who has granted medRxiv a license to display the preprint in perpetuity. It is made available under a CC-BY-ND 4.0 International license .

\title{
Differential COVID-19-attributable mortality and BCG vaccine use in countries
}

\author{
Authors \\ Anita Shet ${ }^{1}$, MD PhD* \\ Debashree Ray, $\mathrm{PhD}$ \\ Neelika Malavige ${ }^{2}$, MBBS PhD \\ Mathuram Santosham ${ }^{1}$, MD \\ Naor Bar-Zeev ${ }^{1}, \mathrm{PhD}$ \\ * Corresponding author
}

${ }^{1}$ International Vaccine Access Center, Department of International Health, Johns Hopkins Bloomberg School of Public Health, Baltimore, USA

${ }^{2}$ Centre for Dengue Research, University of Sri Jayewardenepura, Nugegoda, Sri Lanka

${ }^{3}$ Department of Epidemiology; Department of Biostatistics, Johns Hopkins Bloomberg School of Public Health, Baltimore, USA

\begin{abstract}
While mortality attributable to COVID-19 has devastated global health systems and economies, striking regional differences have been observed. The Bacille Calmette Guérin (BCG) vaccine has previously been shown to have non-specific protective effects on infections, as well as longterm efficacy against tuberculosis. Using publicly available data we built a simple log-linear regression model to assess the association of BCG use and COVID-19-attributable mortality per 1 million population after adjusting for confounders including country economic status (GDP per capita), and proportion of elderly among the population. The timing of country entry into the pandemic epidemiological trajectory was aligned by plotting time since the $100^{\text {th }}$ reported case. Countries with economies classified as lower-middle-income, upper-middle-income and highincome countries (LMIC, UMIC, HIC) had median crude COVID-19 log-mortality of 0.4 (Interquartile Range (IQR) 0.1, 0.4), 0.7 (IQR 0.2, 2.2) and 5.5 (IQR 1.6, 13.9), respectively. COVID-19-attributable mortality among BCG-using countries was 5.8 times lower [95\% CI 1.819.0] than in non BCG-using countries. Notwithstanding limitations due to testing constraints in LMICs, case ascertainment bias and a plausible rise of cases as countries progress along the epidemiological trajectory, these analyses provide intriguing observations that urgently warrant mobilization of resources for prospective randomized interventional studies and institution of systematic disease surveillance, particularly in LMICs.
\end{abstract}


medRxiv preprint doi: https://doi.org/10.1101/2020.04.01.20049478; this version posted April 6, 2020. The copyright holder for this preprint (which was not certified by peer review) is the author/funder, who has granted medRxiv a license to display the preprint in perpetuity. It is made available under a CC-BY-ND 4.0 International license .

\section{Introduction}

Novel SARS-CoV2 continues to wreak global havoc. Mortality is of greatest concern directly influencing national response and policy. Early reports from Hubei province in China reported a case fatality rate (CFR) of $15 \%^{1}$, which with widening surveillance, rapidly decreased to below $3 \%{ }^{2,3}$. As new epidemics began in other countries, early testing strategies focused only on severe cases or contacts of known cases and those with known international travel, leading to positively biased CFR estimates. A high CFR of $7.2 \%$ reported in Italy was attributed to a greater proportion of the elderly in the population and a stringent testing strategy restricted to severe disease cases ${ }^{4}$. With concurrent outbreaks occurring globally, marked discrepancies in CFR became increasingly apparent. In east Asian countries (Vietnam, Thailand, and Philippines), early rises in case incidence have not been followed by similarly sharp CFR increases. CFR estimation is sensitive to testing strategies, initiation of distancing measures, access to healthcare and population age structure. We surmised that since susceptibility to COVID-19 infection extends to the entire population, crude national COVID-19-specific mortality within the country-specific population would be an informative outcome indicator to study differences in mortality patterns amongst countries, in addition to a priori defined potential exposure variables including BCG vaccine use in national immunization schedules.

Among vaccination strategies worldwide, Bacille Calmette Guérin (BCG) vaccine has the widest use and is accompanied by a strong safety profile. It is given in infancy for prevention of severe forms of tuberculosis. Epidemiological and randomized trial evidence suggest a protective effect of BCG on infant mortality via nonspecific heterologous protection against other infections $^{5}$ possibly through innate immune epigenetic mechanisms ${ }^{6,7}$. BCG lowers experimental viremia in adult human volunteers through upregulation of interleukins such as IL$1 \beta^{8}$. In a randomized placebo-controlled trial in Indonesia, BCG given monthly consecutively for 3 months significantly reduced incidence of acute upper respiratory infections among individuals aged $>65$ years ${ }^{9}$. In a trial among Native Americans, BCG vaccination given during childhood showed efficacy in preventing tuberculosis up to 60 years after vaccination, indicating the durability of its protection ${ }^{10}$. Demonstration that exposure to BCG vaccination can ameliorate severe COVID-19 disease and lower mortality could rationalize a therapeutic or preventive strategy that can have immediately deployable global impact. Therefore, using existing publicly available data we examined at the ecological level whether country-level COVID-19 mortality was associated with BCG use in national immunization schedules. 
medRxiv preprint doi: https://doi.org/10.1101/2020.04.01.20049478; this version posted April 6, 2020. The copyright holder for this preprint (which was not certified by peer review) is the author/funder, who has granted medRxiv a license to display the preprint in perpetuity. It is made available under a CC-BY-ND 4.0 International license .

\section{Methods}

National COVID-19-attributable death counts as reported on 29 March 2020 from the Johns Hopkins Coronavirus Resource Center ${ }^{11,12}$ for the top 50 countries reporting highest case events were used to calculate crude COVID-19-attributable mortality per 1 million population. Population and economic data from 2018 (gross domestic product (GDP), and high, middle or low-income status) were derived from the World Bank Population Data and Open Data repository ${ }^{13}$. In order to mitigate the bias centered around the differential epidemic time curves experienced by the different countries, we calculated days from the $100^{\text {th }}$ COVID-19-positive case to align the countries on a more comparable time curve. We included data on BCG vaccine inclusion in national immunization schedules from the BCG World Atlas ${ }^{14}$.

To evaluate the effect of BCG vaccine on mortality attributable to COVID-19, we built a simple log-linear regression model using crude COVID-19-attributable mortality data per 1 million population for each country as outcome, BCG vaccine inclusion in the national immunization schedule as exposure, and adjusted for the effects of the following variables on mortality: country-specific GDP per capita, the percentage of population 65 years and above, and the relative position of each country on the epidemic timeline (days since $100^{\text {th }}$ case reported as of 29 March 2020). The Shapiro-Wilk normality test confirmed that the log-transformed COVID19-specific mortality was normally distributed. As China, a BCG-using country with a large population and a relatively concentrated death count in a single province can conceivably demonstrate an artifically lowered mortality and skew these results towards BCG use, we did a sensitivity analysis by running our model with the same covariate adjustments but without China. All data were analysed using the $\mathrm{R}$ environment for statistical computing (R Core Team $2018)^{15}$.

\section{Results}

The median crude COVID-19 mortality per 1 million population among countries with economies classified as low-middle-income, upper-midle-income and high-income countries (LMIC, UMIC, HIC) were 0.4 (Interquartile Range (IQR) 0.06, 0.4), 0.65 (IQR 0.2, 2.2) and 5.5 (IQR 1.6, 13.9), respectively (Fig. 1). Characteristics of BCG using and non-BCG using countries with respect to the variables considered are shown in supplementary Table S1.

Figure 1: Country economic category and COVID-19-attributable mortality per 1 million population 


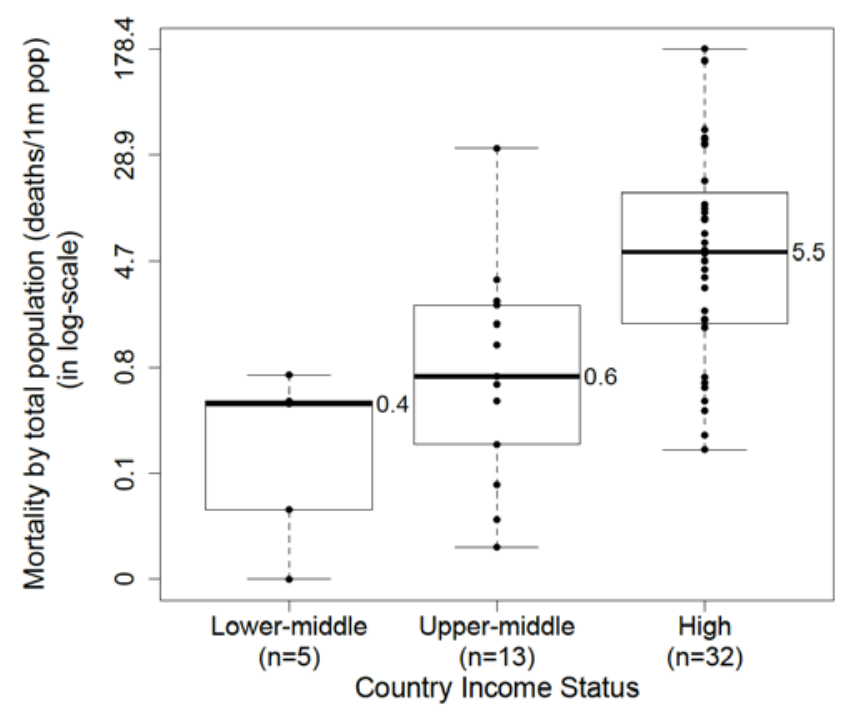

Plotting mortality per 1 million population by BCG use against percentage of the population $\geq$ 65 years (Fig. S1) and the relative position of each country in the epidemiological timeline (Fig. S2) ) along with the characteristics of countries by BCG status (Table S1) suggested possible confounding effects of these variables. The associations of these potentially confounding variables, the outcome and the exposure of interest are represented visually in Fig. 2.

Figure 2: Association between COVID-19-attributable mortality and BCG use in national immunization schedules, propotion of population aged $\geq 65$ years, time trajectory on the epidemiological curve and country-specific GDP per capita. Each dot is representative of a country. Red dots=BCG-using countries; Blue dots=Non BCG-using countries.
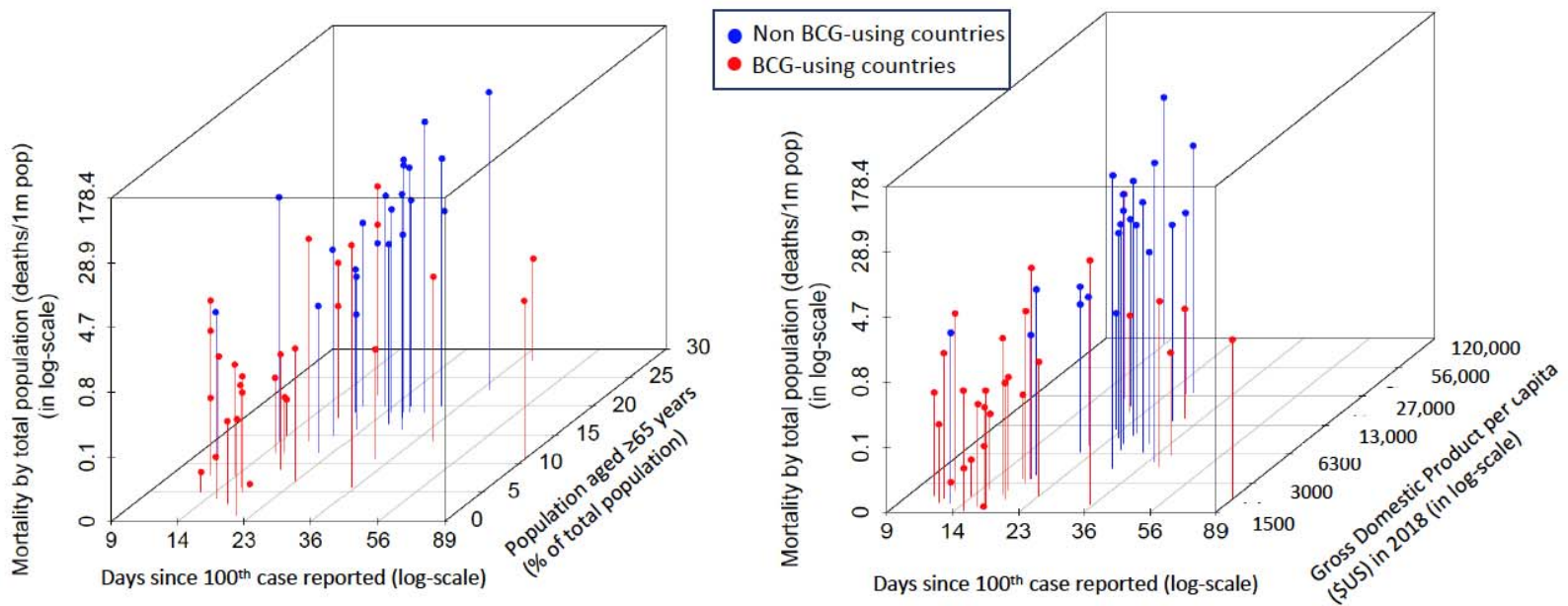

In the log-linear regression adjusted for per capita GDP, age, and time since $100^{\text {th }}$ case, COVID19-attributable mortality among BCG-using countries was 5.8 times lower [95\% Confidence 
Intervals $(\mathrm{CI}) 1.8-19.0$; $\mathrm{p}$ value $=0.006$ ] than in non BCG-using countries (Table 1). The sensitivity analysis run when excluding China from the model resulted in no appreciable change in the BCG effect (5.7 [95\% CI 1.8-18.5]).

Table 1: Log-linear regression model of COVID-19-attributable mortality per 1 million population and $B C G$ use in national immunization schedules, adjusting for relevant covariates. Exponentiated estimates for all parameters are provided.

\begin{tabular}{lll}
\hline Covariate & Estimate & 95\% CI \\
\hline BCG non-use in NIP (Reference group was & 5.78 & $1.75,19.02$ \\
BCG using countries) & & \\
GDP per capita & 1.00 & $0.99,1.00$ \\
Percentage of those aged 65 years and & 1.08 & $0.99,1.17$ \\
above among total population & & \\
Days since $100^{\text {th }}$ reported case & 1.04 & $1.00,1.08$ \\
\hline
\end{tabular}

BCG = Bacille Calmette Guérin vaccine; NIP = national immunization program; GDP = Gross

Domestic Product; $\mathrm{CI}=$ Confidence Interval

\section{Discussion}

The direct association between COVID-19-attributable mortality and country-level economic status observed in this analysis is starkly counterintuitive. Prior global disease burden assessments have suggested that deaths from acute respiratory illness are typically higher in low-income settings due to multiple socio-demographic and economic risk factors ${ }^{16,17}$. Among observed COVID-19-attributable risk factors for disease severity and death, age over 65 years has been identified as a significant factor ${ }^{4,18}$, while it is inferred that LMICs which typically have a younger population structure would potentially experience fewer overall deaths. Another potential confounder was the time lag in deaths following detection of cases. We selected countries with at least 100 reported cases and adjusted for time since this sentinel event. After adjusting for country economic status, proportion of older population and aligning the epidemic trajectories of the highest hit countries, the intriguing observation of a significant association between BCG use and lower COVID-19-attributable mortality remained discernable.

Recent non-peer reviewed work reported a similar negative association between BCG use and COVID-19 mortality ${ }^{19}$. Unlike our report, their findings did not account for potential confounding effects of income status, age structure of the population or timing of the epidemic, and included only 5 BCG non-using countries, making reliable inference challenging. Currently, $\mathrm{BCG}$ vaccine is being considered for clinical trials in different settings to test its ability to 
mitigate infection effects or protect healthcare workers and the elderly population against the SARS-CoV-2 disease ${ }^{20}$.

Several other determinants related to host, viral and environmental factors may be ascribed to these mortality differences. Prevalence of comorbidities such as diabetes, cardiovascular disease, chronic respiratory disease and cancer are rising in LMICs, and in some settings have overtaken HIC. In 2019 non-insulin dependant diabetes mellitus prevalence among adults was reported to be $11 \%$ in Asian countries and $6 \%$ in Europe ${ }^{21}$. The World Health Organization estimates higher cardiovascular disease risk in Asian regions than in European and North American regions ${ }^{22}$. Since we had no access to comprehensive nationally representative comorbidity data, the contribution of disease comorbidity as a population level risk factor for COVID-19-attributable mortality remains unclear.

Genetic risk factors associated with susceptibility to SARS-CoV-2 (in CCL2, mannose binding lectin, CXCL10/IP-10 or ACE2 receptor) are currently under evaluation, and as more evidence accumulates, the role played by these factors may become evident ${ }^{23,24}$. Variations in SARSCoV2 receptor binding domain of the spike protein or nucleocapsid protein could alter disease severity ${ }^{25},{ }^{26}$, although this is more likely to occur in an endemic setting rather than during a pandemic. Temperature and relative humidity may be inversely associated with viral transmissibility. but the association has been modest and inconsistent ${ }^{27,28}$.

Early disease models that used assumptions based on CFRs from China and Italy predicted higher mortality in LMICs, which led to countries adopting severe lockdown measures ${ }^{29}$. Ongoing containment measures are critical for infection transmission mitigation. These measures should be balanced against predicted increases in non-COVID-19 mortality arising directly from economic shutdowns and distancing measures. Severe trade restrictions and lowered productivity can increase poverty and food insecurity globally ${ }^{30}$. Major and prolonged disruptions in crucial health service delivery such as immunization programs or access to emergency obstetric and newborn care can result in a direct increase in preventable deaths, as occurred during and after ebolavirus epidemics ${ }^{31}$. Balancing transmission mitigation against sustaining basic health and nutrition access is a difficult but urgent task.

The limitations in our analyses are important to consider. Deaths lag behind symptomatic infection by 2-8 weeks, and when compared with concurrent incidence cases may underestimate the CFR, although this is less likely to influence cumulative crude mortality ${ }^{32}$. Health system preparedness of each country and the institution of control measures such as social distancing and lockdowns can also determine the cases and mortality numbers. Our data are not meant to falsely reassure countries that their use of BCG may lead to lower mortality. Indeed, our analysis is ecological, does not take into account present BCG coverage, nor timing of BCG 
medRxiv preprint doi: https://doi.org/10.1101/2020.04.01.20049478; this version posted April 6, 2020. The copyright holder for this preprint (which was not certified by peer review) is the author/funder, who has granted medRxiv a license to display the preprint in perpetuity. It is made available under a CC-BY-ND 4.0 International license .

vaccine introduction into national schedules, and is not based on a randomized comparison. By far the most important source of unmeasured confounding in our analysis relates to differential testing and reporting. Limited laboratory surveillance availability and access to facility-based care is common in countries using BCG. Substantial case underascertainment or under-reporting of deaths can magnify any association between mortality and BCG use. In exponential functions, small iterations in time result in substantial changes in outcome. Our findings need to be interpreted with caution; given vulnerable health systems and high levels of comorbidities in LMICs, if an exponential rise of cases followed by deaths were to occur in ensuing weeks, this would alter the epidemiological predictions in this report.

Despite all these caveats, the inverse relationship between country economic status and COVID19-attributable mortality, and the strong ecological association with BCG vaccination are intriguing. The findings warrant deeper epidemiological scrutiny and prospective evaluation in individually randomized trials. Importantly the findings in this report illustrate the pivotal role that continuous systematic laboratory surveillance will have in improving our understanding of the pandemic, particularly in LMICs. Such data lead to informed policy making that are beneficial to health and economic outcomes.

\section{References}

1. Huang C, Wang Y, Li X, et al. Clinical features of patients infected with 2019 novel coronavirus in Wuhan, China. Lancet. 2020;395(10223):497-506.

2. Chang, Lin M, Wei L, et al. Epidemiologic and Clinical Characteristics of Novel Coronavirus Infections Involving 13 Patients Outside Wuhan, China. JAMA : the journal of the American Medical Association. 2020.

3. Wu Z, McGoogan JM. Characteristics of and Important Lessons From the Coronavirus Disease 2019 (COVID-19) Outbreak in China: Summary of a Report of 72314 Cases From the Chinese Center for Disease Control and Prevention. JAMA : the journal of the American Medical Association. 2020.

4. Onder G, Rezza G, Brusaferro S. Case-Fatality Rate and Characteristics of Patients Dying in Relation to COVID-19 in Italy. JAMA : the journal of the American Medical Association. 2020.

5. Shann F. Nonspecific effects of vaccines and the reduction of mortality in children. Clin Ther. 2013;35(2):109-114.

6. Moorlag S, Arts RJW, van Crevel R, Netea MG. Non-specific effects of BCG vaccine on viral infections. Clinical microbiology and infection. 2019;25(12):1473-1478.

7. Kleinnijenhuis J, Quintin J, Preijers F, et al. Bacille Calmette-Guerin induces NOD2dependent nonspecific protection from reinfection via epigenetic reprogramming of 
medRxiv preprint doi: https://doi.org/10.1101/2020.04.01.20049478; this version posted April 6, 2020. The copyright holder for this preprint

(which was not certified by peer review) is the author/funder, who has granted medRxiv a license to display the preprint in perpetuity.

It is made available under a CC-BY-ND 4.0 International license .

monocytes. Proceedings of the National Academy of Sciences of the United States of America. 2012;109(43):17537-17542.

8. Arts RJW, Moorlag S, Novakovic B, et al. BCG Vaccination Protects against Experimental Viral Infection in Humans through the Induction of Cytokines Associated with Trained Immunity. Cell Host Microbe. 2018;23(1):89-100.e105.

9. Wardhana, Datau EA, Sultana A, Mandang VV, Jim E. The efficacy of Bacillus CalmetteGuerin vaccinations for the prevention of acute upper respiratory tract infection in the elderly. Acta Med Indones. 2011;43(3):185-190.

10. Aronson NE, Santosham M, Comstock GW, et al. Long-term efficacy of BCG vaccine in American Indians and Alaska Natives: A 60-year follow-up study. JAMA : the journal of the American Medical Association. 2004;291(17):2086-2091.

11. Coronavirus COVID-19 Global Cases by the Center for Systems Science and Engineering (CSSE) at Johns Hopkins University, Available at https://coronavirus.jhu.edu/map.html Time Series data available at: https://github.com/CSSEGISandData/COVID19/tree/master/csse_covid_19_data/csse_covid_19_daily_reports. Accessed on 29 March 2020.

12. Dong E, Du H, Gardner L. An interactive web-based dashboard to track COVID-19 in real time. The Lancet infectious diseases. 2020.

13. World Bank Population and Open Data repository. Available at https://data.worldbank.org/indicator/SP.POP.TOTL?most_recent_value_desc=true. Accessed on 26 March, 2020.

14. BCG World Atlas, 2nd Edition, A database of global BCG vaccination policies and practices, McGill University and Public Health Agency of Canada. Available at: http://www.bcgatlas.org/ Accessed on 26 March 2020.

15. R Core Team (2018) R: A Language and Environment for Statistical Computing. R Foundation for Statistical Computing, Vienna. Available at: https://www.R-project.org.

16. Sonego M, Pellegrin MC, Becker G, Lazzerini M. Risk factors for mortality from acute lower respiratory infections (ALRI) in children under five years of age in low and middleincome countries: a systematic review and meta-analysis of observational studies. PloS one. 2015;10(1):e0116380.

17. Khaltaev N, Axelrod S. Chronic respiratory diseases global mortality trends, treatment guidelines, life style modifications, and air pollution: preliminary analysis. J Thorac Dis. 2019;11(6):2643-2655.

18. Severe Outcomes Among Patients with Coronavirus Disease 2019 (COVID-19) - United States, February 12-March 16, 2020. MMWR Morbidity and mortality weekly report. 2020;69(12):343-346.

19. Miller A, Reandelar MJ, Fasciglione K, Roumenova V, Li Y, Otazu GH. Correlation between universal BCG vaccination policy and reduced morbidity and mortality for COVID-19: an epidemiological study. medRxiv. 2020:2020.2003.2024.20042937. 
medRxiv preprint doi: https://doi.org/10.1101/2020.04.01.20049478; this version posted April 6, 2020. The copyright holder for this preprint

(which was not certified by peer review) is the author/funder, who has granted medRxiv a license to display the preprint in perpetuity.

It is made available under a CC-BY-ND 4.0 International license .

20. BCG Vaccine trial for COVID-19, Science Alert, 27 March 2020, Available at https://www.sciencealert.com/australia-is-trialling-a-tb-vaccine-for-coronavirus-andhealth-workers-get-it-first.

21. The Diabetes Atlas, 9th Edition. International Diabetes Federation, Available at https://www.diabetesatlas.org/en/sections/demographic-and-geographic-outline.html. Accessed on 29 March 2020. 2019.

22. World Health Organization cardiovascular disease risk charts: revised models to estimate risk in 21 global regions. The Lancet Global health. 2019;7(10):e1332-e1345.

23. Tu X, Chong WP, Zhai Y, et al. Functional polymorphisms of the CCL2 and MBL genes cumulatively increase susceptibility to severe acute respiratory syndrome coronavirus infection. The Journal of infection. 2015;71(1):101-109.

24. Cao Y, Li L, Feng Z, et al. Comparative genetic analysis of the novel coronavirus (2019nCoV/SARS-CoV-2) receptor ACE2 in different populations. Cell Discov. 2020;6:11.

25. Andersen KG, Rambaut A, Lipkin WI, Holmes EC, Garry RF. The proximal origin of SARS-CoV-2. Nature medicine. 2020.

26. Phan T. Genetic diversity and evolution of SARS-CoV-2. Infection, genetics and evolution : journal of molecular epidemiology and evolutionary genetics in infectious diseases. 2020;81:104260.

27. Wang J, Tang K, Feng K, Lv W. High Temperature and High Humidity Reduce the Transmission of COVID-19 (March 9, 2020). Available at SSRN: https://ssrn.com/abstract=3551767 or http://dx.doi.org/10.2139/ssrn.3551767 2020.

28. Bannister-Tyrrell M, Meyer A, Faverjon C, Cameron A. Preliminary evidence that higher temperatures are associated with lower incidence of COVID-19, for cases reported globally up to 29th February 2020. medRxiv. 2020:2020.2003.2018.20036731.

29. Prem K, Liu Y, Russell TW, et al. The effect of control strategies to reduce social mixing on outcomes of the COVID-19 epidemic in Wuhan, China: a modelling study. Lancet Public Health. 2020.

30. Vos R, Martin W, Laborde D. How much will global poverty increase because of COVID19? In:2020.

31. Brolin Ribacke KJ, Saulnier DD, Eriksson A, von Schreeb J. Effects of the West Africa Ebola Virus Disease on Health-Care Utilization - A Systematic Review. Front Public Health. 2016;4:222.

32. Baud D, Qi X, Nielsen-Saines K, Musso D, Pomar L, Favre G. Real estimates of mortality following COVID-19 infection. The Lancet infectious diseases. 2020. 

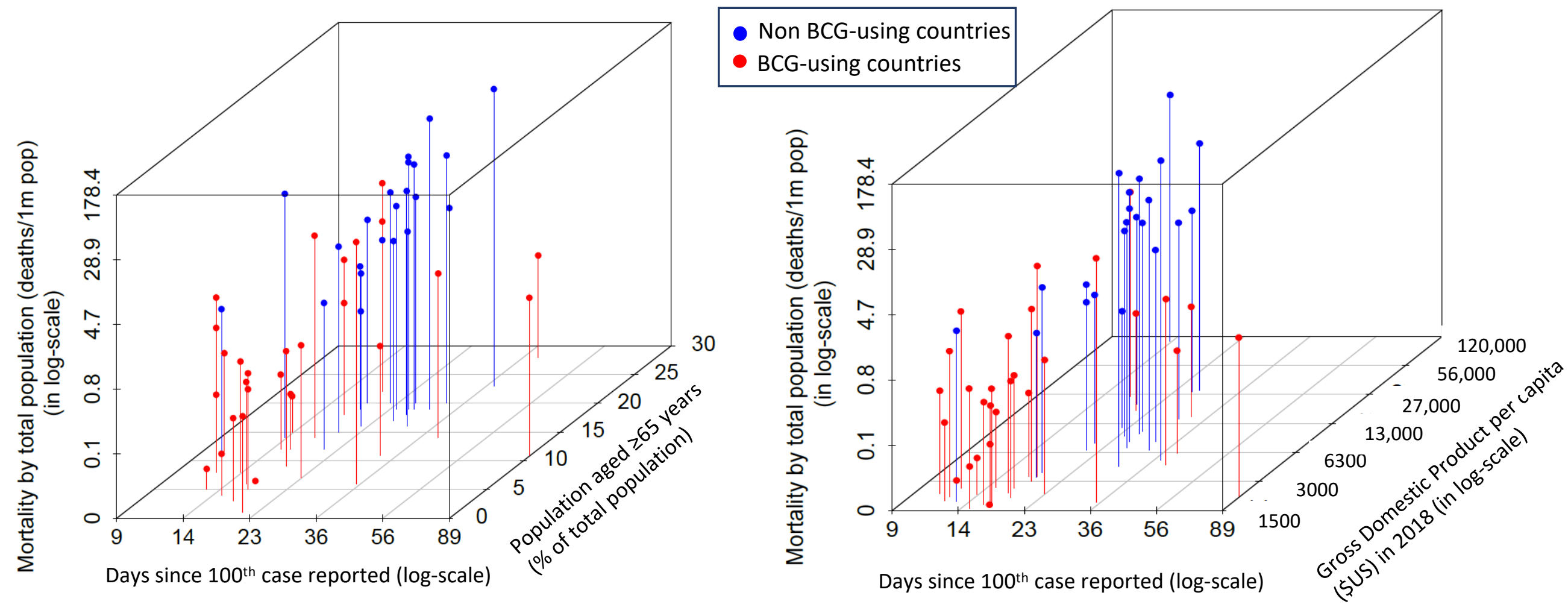